\title{
Simulating river flow velocity on global scale
}

\author{
K. Schulze ${ }^{1}$, M. Hunger ${ }^{2}$, and P. Döll ${ }^{2}$ \\ ${ }^{1}$ Center for Environmental Systems Research, University of Kassel, Germany \\ ${ }^{2}$ Institute of Physical Geography, Johann Wolfgang Goethe University, Frankfurt, Germany
}

Received: 7 January 2005 - Revised: 1 August 2005 - Accepted: 1 September 2005 - Published: 16 December 2005

\begin{abstract}
Flow velocity in rivers has a major impact on residence time of water and thus on high and low water as well as on water quality. For global scale hydrological modeling only very limited information is available for simulating flow velocity. Based on the Manning-Strickler equation, a simple algorithm to model temporally and spatially variable flow velocity was developed with the objective of improving flow routing in the global hydrological model of WaterGAP. An extensive data set of flow velocity measurements in US rivers was used to test and to validate the algorithm before integrating it into WaterGAP. In this test, flow velocity was calculated based on measured discharge and compared to measured velocity. Results show that flow velocity can be modeled satisfactorily at selected river cross sections. It turned out that it is quite sensitive to river roughness, and the results can be optimized by tuning this parameter. After the validation of the approach, the tested flow velocity algorithm has been implemented into the WaterGAP model. A final validation of its effects on the model results is currently performed.
\end{abstract}

\section{Introduction}

River flow velocity is crucial to simulate discharge hydrographs and the residence time of water in the hydrological system. If a single or a limited number of catchments are modeled, complex flow velocity equations can be parameterized with observed catchment-specific values. This is not possible at larger scales. Hence, for a global approach, a simplified methodology is needed. In state-of-the-art global hydrological models, either no lateral routing and thus no river flow velocity is used (Arnell, 1999; Yates, 1997) or just simple approaches like constant river flow velocity (Döll et al., 2003), simple functions of discharge (Vörösmarty et al., 1989) or of topography (Hagemann and Dümenil, 1998) are

Correspondence to: K. Schulze

(schulze@usf.uni-kassel.de) applied to simulate flow velocity or retention time in rivers, respectively. In general these models are designed to model mean long-term discharges and for these cases it is sufficient to use simple approaches. However, to model flood events or water quality, it is necessary to use a more sophisticated approach.

In this work a simple algorithm to model flow velocity based on a limited number of parameters is presented. The approach allows simulating spatially and temporally variable river flow velocities based on parameters derived from globally available data and discharge time series, that might be provided by measurements or by spatially distributed hydrological models. It was tested against independent flow velocity measurements at several river cross sections. The longterm objective of these efforts is to improve flow routing in the WaterGAP Global Hydrology Model, WGHM (Döll et al., 2003), which was designed to assess and predict water availability at the global scale with a spatial resolution of 0.5 by 0.5 degrees.

\section{Methodology}

To determine river velocity at the global scale, an approach had to be found, simple enough that the required parameters could be derived from data globally available and sophisticated enough to deliver realistic flow velocity values for a large variety of environmental conditions. The ManningStrickler formula (Eq. 1), one of the best known and most often used equations to calculate river flow velocity, is considered to meet these demands.

$v=n^{-1} \cdot R^{2 / 3} \cdot S^{1 / 2} \quad[\mathrm{~m} / \mathrm{s}]$

In Eq. (1), $v$ is the flow velocity $[\mathrm{m} / \mathrm{s}], n$ is the river bed roughness [-], $R$ the hydraulic radius $[\mathrm{m}]$ and $S$ the river slope $[\mathrm{m} / \mathrm{m}]$.

The hydraulic radius $(R)$ of a specific river cross section is temporally variable due to river stage dynamics. It depends on the shape of the river bed profile and the actual water level. 
Table 1. Gauging stations used for model testing with optimized roughness and modeling efficiency (NSC).

\begin{tabular}{|c|c|c|c|c|c|c|c|c|}
\hline \multirow{2}{*}{ River/Site } & \multirow{2}{*}{ State } & \multirow{2}{*}{$\begin{array}{l}\text { Basin area } \\
{\left[1000 \mathrm{~km}^{3}\right]}\end{array}$} & \multirow{2}{*}{$\begin{array}{c}\text { No. of } \\
\text { measurements }\end{array}$} & \multirow{2}{*}{$\begin{array}{l}\text { Slope (from WGHM) } \\
{[\mathrm{m} / \mathrm{m}]}\end{array}$} & \multirow{2}{*}{$\begin{array}{l}\text { Roughness } \\
\text { adj. }\end{array}$} & \multicolumn{2}{|c|}{ Mean velocity } & \multirow{2}{*}{ NSC } \\
\hline & & & & & & $\bmod .[\mathrm{m} / \mathrm{s}]$ & meas. $[\mathrm{m} / \mathrm{s}]$ & \\
\hline Kuskokwim/Crooked Creek & $\mathrm{AK}$ & 80.5 & 134 & 0.0001 & 0.021 & 1.01 & 0.94 & 0.70 \\
\hline Yukon/Pilot Station & $\mathrm{AK}$ & 831.4 & 107 & 0.0001 & 0.036 & 0.88 & 0.86 & 0.57 \\
\hline Connecticut/Thompsonville & CT & 24.9 & 92 & 0.0010 & 0.063 & 0.86 & 0.79 & 0.58 \\
\hline Apalachicola/Chattahoochee & FLA & 44.5 & 168 & 0.0003 & 0.060 & 0.52 & 0.51 & 0.49 \\
\hline Ohio/Metropolis & IL & 525.8 & 96 & 0.0002 & 0.058 & 0.87 & 0.82 & 0.49 \\
\hline Mississippi/Clinton & IA & 221.7 & 287 & 0.0004 & 0.077 & 0.58 & 0.57 & 0.55 \\
\hline Penobscot/West Enfield & ME & 17.3 & 64 & 0.0011 & 0.071 & 0.72 & 0.70 & 0.58 \\
\hline Missouri/Culbertson & MT & 237.1 & 104 & 0.0002 & 0.028 & 0.74 & 0.73 & 0.60 \\
\hline Roanoke/Roanoke Rapids & $\mathrm{NC}$ & 21.7 & 56 & 0.0008 & 0.060 & 0.62 & 0.60 & 0.59 \\
\hline Red River North/Grand Forks & ND & 68.1 & 630 & 0.0001 & 0.023 & 0.58 & 0.56 & 0.71 \\
\hline Missouri/Nebraska City & NE & 1061.9 & 1843 & 0.0004 & 0.031 & 1.36 & 1.38 & 0.59 \\
\hline Humbold/Imlay & NV & 40.2 & 297 & 0.0008 & 0.041 & 0.37 & 0.37 & 0.59 \\
\hline Arkansas/Tulsa & OK & 160.8 & 133 & 0.0004 & 0.037 & 0.78 & 0.75 & 0.78 \\
\hline Rogue/Agness & OR & 10.2 & 96 & 0.0001 & 0.016 & 0.76 & 0.71 & 0.53 \\
\hline Brazos/Richmond & TX & 92.1 & 188 & 0.0003 & 0.039 & 0.57 & 0.55 & 0.69 \\
\hline Sevier/Juab & UT & 13.4 & 214 & 0.0009 & 0.035 & 0.46 & 0.47 & 0.74 \\
\hline
\end{tabular}

Assuming that the river bed is shaped as a rectangle it can be calculated as a function of river depth $(D,[\mathrm{~m}])$ and width $(W,[\mathrm{~m}])$.

$R=\frac{D \cdot W}{2 D+W} \quad[\mathrm{~m}]$

Continuous data on river width and depth is lacking at the global scale. Based on the close relationship between channel form and discharge $(Q,[\mathrm{~m} / \mathrm{s}])$, Leopold and Maddock (1953) introduced equations, which estimate these parameters as a function of discharge:

$W=a \cdot Q^{b} \quad[\mathrm{~m}]$

$D=c \cdot Q^{f} \quad[\mathrm{~m}]$

Equations (3) and (4) can be found in recent hydrology textbooks (e.g. Mosley and McKerchar, 1993 (p. 8.4); Dunne and Leopold, 1978 (p. 637)) and are frequently applied. Allen et al. (1994) carried out a regression analysis with a dataset of 674 river cross sections across the USA and Canada to quantify the best-fit coefficients $(a, c)$ and exponents $(b, f)$ in the equations, valid for bankfull discharge $\left(Q_{b}\right)$ :

$$
\begin{aligned}
& W=2.71 \cdot Q_{b}^{0.557} \quad[\mathrm{~m}] \\
& D=0.349 \cdot Q_{b}^{0.341} \quad[\mathrm{~m}]
\end{aligned}
$$

During regression analysis, Allen et al. (1994) obtained high coefficients of determination $\left(r^{2}\right)$ of 0.88 and 0.75 for width and depth.

In this approach of modeling river velocity, it is assumed that the hydraulic radius of a non-bankfull river follows the same geometric rules as bankfull discharge. Hence Eqs. (5) and (6) are used to calculate the hydraulic radius in Eq. (2) for all discharges. Assuming that major rivers tend to have a nearly flat river bed and their width exceeds their depth by far, the assumption of a rectangular cross section is considered as acceptable for bankful discharge. For less than bankfull discharge, which is the normal case, width and depth are scaled, but their ratio remains the same. Under natural conditions, in a flat and broad river bed, depth would decrease faster than width with falling discharge. Hence the model tends to overestimate the ratio of depth to width. As the hydraulic radius and thus river velocity are especially sensitive to changes in depth with this first approach velocity results for less than bankful discharge will be overestimated which has to be kept in mind regarding the results.

River slope values $(S,[\mathrm{~m} / \mathrm{m}])$ are determined for each cell of a global $0.5^{\circ}$ grid by GIS analysis of a digital elevation model with a resolution of 3 arc $\min (10 \times 10$ values per grid cell). The $0.5^{\circ}$ grid has been chosen for compatibility reasons with regard to the spatial resolution of WGHM. One cell's outflow level is estimated as mean of the five lowest elevation values at the respective cell. The slope of a river segment is calculated as elevation difference between up- and downstream cell outflow levels, divided by the product of their horizontal distance and a meandering factor which was arbitrary estimated at 1.3 as global average. The estimation of the meandering factor is based on a visual analysis of a map of actual river courses and an abstracted $0.5^{\circ}$ drainage direction map that connects up- and downstream cells with a straight line. Although the meandering factor varies spatially it is assumed that the approximation reflects reality better than using the distance between neighbouring cell centers only.

Values of Manning's roughness $(n,[-])$ vary between 0.015 and 0.07 in natural streams for flows less than bankfull discharge and reach up to 0.25 for overbank flows (Fread, 1993 , p. 10.25). There is very few local data and no way to assess river roughness at the global scale. Therefore three 
options to estimate river roughness globally were identified.

1. use of roughness as tuning factor (based on discharge or velocity data) and regionalize in basins whithout validation data;

2. use of constant river roughness;

3. use of topographic and/or geologic information to estimate river roughness for each grid cell.

For the model-tests performed, roughness was determined by tuning or set constant.

\section{Results}

\subsection{Testing the approach}

The modeling approach was tested for single river cross sections by comparing the results to an independent set of measured river velocity data. While the USGS (United States Geological Survey) provides an extensive dataset of surface water measurements for the United States of America (U.S. Geological Survey, 2001), it turned out to be difficult to find stream flow and velocity data for other parts of the world. Thus only U.S. data could be used to validate the modeling approach. A subset of the USGS data was generated that includes 16 gauging stations representing a variety of climatic and topographic conditions as well as different basin sizes between Alaska and Florida (see Table 1). The validation dataset covers the period from 1970 to 2004 and contains a total of 4500 measurements of actual flow velocity and discharge.

Manning's roughness $(n)$ was adjusted for each station to maximize modeling efficiency (Nash-Sutcliffe coefficient, NSC) which relates the goodness-of-fit of the model to the variance of the measurement data.

Table 1 shows the modeling efficiency for tuned roughness values at the 16 stations. NSC values vary from 0.49 to 0.78 (the optimum would be 1.0). Taking into account, the only temporally variable input data was discharge (Eqs. 5 and 6) all modeling results are considered satisfactory. Since it will not be possible to optimize $\mathrm{n}$ by measured velocity data in a global application, it was additionally attempted to run the model with just one, average n (0.044) for all stations. Even without adjusting roughness, at 12 of the 16 stations model results proved to be better than a constant velocity of $1 \mathrm{~m} / \mathrm{sec}$ which has been used in WGHM so far (not in the table). Using $1 \mathrm{~m} / \mathrm{sec}$ constantly would lead to NSC values below zero for all stations (not in the table).

Measured and modeled river velocity from three selected stations are compared in Fig. 1. It can clearly be seen, that the new approach estimates flow velocity far better than WGHMs hithero used constant velocity of $1 \mathrm{~m} / \mathrm{sec}$ (bold dashed line). Thus, the figure supports the idea of improving the flow velocity simulation within the global hydrology model WGHM.

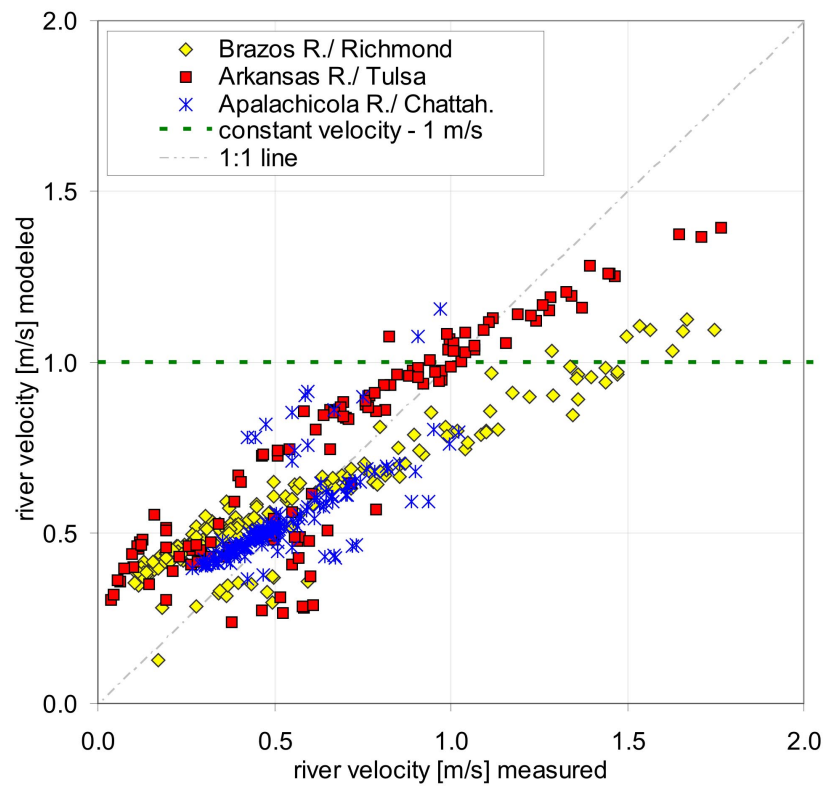

Fig. 1. Modeled values of river velocity compared to measured values for three selected stations.

In general, the modeling approach tends to overestimate flow velocity for low discharges and to underestimate it for high discharges (see Sect. 2). This suggests an imprecise determination of the hydraulic radius (too big for low discharges and vice versa). This is probably due to the approach itself (Eq. 5 and 6) which is only valid for bankfull discharge. Discrepancies between modeled and measured velocity could also be due to uncertainties in the regression analysis carried out by Allen et. al. (1994). Further, slope input into the model only represents a mean value for a $0.5^{\circ}$ grid cell and is projected to the location of a single gauging station. Even the flow velocity measurements might contain errors because this parameter is not easy to measure.

\subsection{Integrating the algorithm into a global hydrology model}

Despite of the remaining uncertainties the new river flow velocity algorithm was integrated into the WaterGAP Global Hydrology Model (WGHM) for a tentative evaluation. The objective was to gain experience in the technical feasibility on the one hand and to get an impression of model performance in different parts of the world on the other hand.

It turned out that the flow routing time step (two hours in the standard version of WGHM with constant velocity) had to be adjusted dynamically. For numerical stability higher flow velocities require shorter routing time steps. To avoid excessive simulation durations, caused by very short time steps, a maximum flow velocity can be defined by the model user.

Preliminary tests of the new approach whithin WGHM were conducted for several river basins around the world. Results are rather encouraging since at least, minor improvements in modeling efficiency could be achieved for all sites 
tested. However, roughness adjustment and validation of the results could yet only be performed based on monthly discharge values which are, for almost all rivers, not very sensitive to river velocity.

To find out how much effort is adequate to put into the estimation of river roughness (see Sect. 2), its sensitivity to discharge and the mean residence time of water in a river basin need to be investigated in detail using WGHM results. Here it has also be taken into account that the influence of other processes within the hydrological cycle might overlap the influence of roughness. For example, routing through lakes and wetlands has a major impact on simulated discharge and residence time, and is not affected by the new flow velocity algorithm.

\section{Conclusions}

The goal was to find an algorithm appropiate to model flow velocity in a large scale hydrological model. In this paper, we present a simple approach which is based on the ManningStrickler equation and the correlation of river discharge and river width and depth.

- A comparison at 16 selected US gauging stations showed that simulated river velocity fits measured values quite well, indicating a significant improvement over a constant flow velocity.

- Model results are very sensitive to river roughness. The impact of roughness on discharge and residence time will be investigated in more detail using WGHM. A method to estimate river roughness globally needs to be defined.

- The approach has been found suitable to be integrated into the global model WGHM for further investigation. First test runs are encouraging.

The validation of the flow velocity impact on WGHM results is not yet finished. Depending on the validation results, the approach might still be modified. As the computation of river width and depth is based on Eqs. (5) and (6), valid only for bankfull discharge, further improvements might be achieved by integrating an approach for non-bankfull discharge.
Edited by: P. Krause, K. Bongartz, and W.-A. Flügel

Reviewed by: anonymous referees

\section{References}

Allen, P. M., Arnold, J. G., and Byars, B. W.: Downstream channel geometry for use in planning-level models, Water Resources Bulletin, 30(4), 663-671, 1994.

Arnell, N. W.: A simple water balance model for the simulation of streamflow over a large geographic domain, J. Hydrol., 217, 314-335, 1999.

Döll, P., Kaspar, F., and Lehner, B.: A global hydrological model for deriving water availability indicators: model tuning and validation, J. Hydrol., 270, 105-134, 2003.

Dunne, T. and Leopold, L. B.: Water in Environmental Planning, 13th edition, W.H. Freeman and Company, New York, 818 pp., 1978.

Fread, D. L.: Flow Routing, in: Handbook of Hydrology, edited by: Maidment, D. R., McGraw-Hill, New York, pp. 10.1-10.36, 1993.

Hagemann, S. and Dümenil, L.: A parameterization of the lateral water flow for the global scale, Clim. Dynam., 14, 17-31, 1998.

Leopold, L. and Maddock, T.: The hydraulic geometry of stream channels and some physiographic implications: Professional Paper 252, United States Geological Survey, 1953.

Mosley, M. P. and McKerchar, A. I.: Streamflow, in: Handbook of Hydrology, edited by: Maidment, D. R., McGraw-Hill, New York, pp. 8.1-8.39, 1993.

U.S. Geological Survey: National Water Information System (NWISWeb), http://waterdata.usgs.gov/nwis/ (26.08.2004), 2001.

Vöröshmarty, C. J., Moore, B., Grace, A. L., and Gildea M. P.: Continental scale models of water balance and fluvial transport: an application to South America, Global Biogeochem. Cycl., 3(3), 241-265, 1989.

Yates, D. N.: Approaches to continental scale runoff for integrated assessment models, J. Hydrol., 201, 289-310, 1997. 